\title{
The modern slavery regime: a critical evaluation
}

\section{AGNES SIMIC and BRAD K. BLITZ}

Abstract: This article sets the context to this special issue: it discusses the background to the UK Modern Slavery Act 2015 and related legislative and policy instruments and sets out a methodology for comparing modern slavery in a global context. Developing the findings of a joint British Academy-DFID programme, 'Tackling Slavery, Human Trafficking and Child Labour in Modern Business', it describes a modern slavery regime defined by the production and implementation of laws and policies at both the international and the domestic level that specifically seeks to address a series of abuses associated with the term 'modern slavery'. The article interrogates the effectiveness of law and policy in curbing abuse and considers how societal and cultural norms impact on the ways in which modern slavery is conceptualised. It also suggests ways in which contributions to this special issue may advance our understandings of the modern slavery regime and where efforts to address modern slavery fall short.

Keywords: Effectiveness, implementation, modern slavery, Modern Slavery Act, modern slavery regime.

\section{INTRODUCTION}

When the UK government introduced the Modern Slavery Act (MSA) 2015, it was claimed that the legislation aimed to lay the basis for more coordinated policy, especially as it regarded existing anti-slavery and anti-trafficking provisions (Haynes 2016). In practice, the act did so by promoting the use of transparency and voluntary disclosure to combat extreme forms of exploitation in supply chains (Bloomfield \& LeBaron 2018), with varying results. This article examines the context behind the development of a 'regime' on modern slavery and introduces the articles that follow. While there are many definitions, we note that a regime may be defined as a 'set of explicit or implicit principles, norms, rules and decision-making procedures around which actor expectations converge in a given issue-area' (Krasner 1982: 185).

The articles included in this volume are the result of research funded under a joint British Academy-DFID (Department for International Development) programme, 'Tackling Slavery, Human Trafficking and Child Labour in Modern Business'. Together they address the modern slavery regime from a number of angles, interrogating the 
effectiveness of law and policy in curbing abuse, and exploring how cultural and societal norms influence the ways in which modern slavery is understood. Although modern slavery is not geographically restricted, we note that the discourse on the eradication of modern slavery reflects certain normative trends among states in the Global North. The articles in this special issue, however, focus principally on the Global South, where the modern slavery regime is compromised by various levels of governance, both overtly and covertly. While corrective laws exist in both the North and Global South, we note that in the South in particular, these are often perfunctory and are used to satisfy international agendas and country commitments or to enhance the perception of the country and its position in the global outsourcing business.

We suggest that a modern slavery regime may be inferred by the production of laws and policies at both the international and the domestic level that specifically seek to address a series of abuses that have been described under the rubric of modern slavery. This article discusses the background to the MSA and related legislative and policy instruments and sets out a methodology for comparing modern slavery in a global context before outlining how the contributions to this special issue may advance our understanding of the modern slavery regime and where it falls short of meeting its objectives.

\section{FROM INTERNATIONAL LAW TO DOMESTIC POLICY: THE EMERGENCE OF A REGIME ON MODERN SLAVERY}

The enactment of the UK Modern Slavery Act (MSA) 2015 was heralded as the first such legislation in Europe and one of the first in the world to address modern slavery as a specific set of abuses, after Brazil amended Article 149 of its penal code in 2003 to enlarge the definition of the crime of submitting someone to a 'condition analogous to slavery' and California introduced the Transparency in Supply Chains Act in 2010. Yet the UK law was a novel addition, not least because under Section 54, the MSA requires UK-based commercial organisations that supply goods or services and have an annual global turnover of more than $£ 36$ million to prepare an annual statement on modern slavery and human trafficking. Within four years, the law has served to inspire new legislation in other jurisdictions, and a new regime on modern slavery has quickly developed. This regime was built in part on previous international commitments, including the United Nations Trafficking Protocol (UN 2000), the Council of Europe Anti-Trafficking Convention (Council of Europe 2005), and the EU AntiTrafficking Directive (EU 2011) and was supported by the introduction of new legislation. In addition, it was sustained by active anti-trafficking campaigns, victim support, and rescue efforts which were assisted by a national hotline. 
Critics noted that Section 54, which emphasises the logic of transparency, sat, at times awkwardly, next to a human rights framework that had been boosted following the creation of the UN's Sustainable Development Goals (UN 2015) and in particular SDG 8.7, which after some protest, was accepted by 193 countries. Specifically, SDG 8.7 set out measurable targets to end modern slavery offences and called upon states to take:

immediate and effective measures to eradicate forced labour, end modern slavery and human trafficking and secure the prohibition and elimination of the worst forms of child labour, including recruitment and use of child soldiers, and by 2025 end child labour in all its forms (Freedom United 2019).

For many years, states had been bound by existing international obligations which both protected the right to be free of slavery and established it as a basic human right. For example, within human rights law, legislation against slavery had secure foundations. Slavery and slavery-type situations are prohibited in both national and international laws including the 1950 European Convention for the Protection of Human Rights and Fundamental Freedoms under Article 4. The International Covenant on Civil and Political Rights (1966) also covers freedom from slavery under Article 8, ${ }^{1}$ as do many International Labour Organization (ILO) conventions. In fact, the ILO Conventions both pre-date the UN's human rights instruments and raise issues which are now considered to be central to the modern slavery regime, including the use of remedies. We note that the ILO Convention Concerning Forced or Compulsory Labour (Forced Labour Convention, C029 (ILO 1930)) was adopted to prohibit slavery and forced labour from as far back as 1930. Most importantly, this early convention saw eradication as a process. ${ }^{2}$ A second ILO Convention on the Abolition of Forced Labour (C105 (ILO 1957)) identified the ways in which forced labour had been used to advance not only economic gain but also political agendas. It highlighted the need to suppress forced and compulsory labour as a means of political punishment against those with opposing conscientious views, who have participated in strikes, who have faced discrimination on various grounds such as race and ethnicity, and as a means of economic advancement by the state (Article 1). Most importantly, the ILO later expanded our understanding of abuses to include slavery-like practices such as

\footnotetext{
${ }^{1}$ Similarly, other regional instruments have provisions affirming the right to be free; see the American Convention on Human Rights (Article 6) of 1969, and more recently the African Charter on Human and Peoples' Rights (Article 5) of 1982.

${ }^{2}$ It called upon states 'to suppress the use of forced or compulsory labour in all its forms within the shortest possible period' (Article 1), with some exceptions such as for public purposes, and ultimately and gradually to eradicate it altogether.
} 
debt-bondage, serfdom, forced marriage, bride sale, bride inheritance, and-for the first time in international law-forced child labour (Article 1). ${ }^{3}$

While the above international human rights conventions were well established, several decades elapsed before the adoption of stronger international legal instruments on forced and child labour, specifically. These include the 1998 Declaration on Fundamental Principles and Rights at Work (ILO 1998); the 1999 Worst Forms of Child Labour Convention (C182 (ILO 1999)); and 2014 Protocol to the Forced Labour Convention, 1930 (P029 (ILO 2014)). Arguably the emergence of new instruments in the late 1990s laid the ground for the legal regime we associate with the modern slavery challenge known today: a collection of commitments building on the UN Guiding Principles on Business and Human Rights (UN 2011), UN human rights conventions, and ILO legislation, in addition to the growing body of national legislation. What was most significant about these legal developments is the three-part approach of prevention, protection, and remedies in relation to forced and compulsory labour-an approach set out in the UN Guiding Principles, a 'global authoritative standard' (Ra'ad Al Hussein 2015).

Furthermore, within public international law the prohibition of slavery has been established as an obligation falling on states with the status of jus cogens (Verdross 1966) and having erga omnes effect (Bassiouni 1998). This status requires all states to prevent, sanction, prosecute, and punish slavery as an obligation 'that every state owes to all others' (Bassiouni 1998). For this reason, some suggest that modern slavery should be considered a crime with universal jurisdiction that in certain instances could amount to the level of a crime against humanity (Cockayne et al. 2016). Although public international law has been gradually weakened (especially in relation to business practices) to the detriment of private international law (Ruggie 2017), the place of slavery within public international law has great influence on discourse and social practice.

Recognising the normative dimension of modern slavery within international law, a group of academics and non-governmental organisations has further extended the regime by drawing upon examples of 'modern-day slavery'. Most prominent among these is Nottingham University sociologist Kevin Bales (1999). Since the late 1990s, and in no small measure as a result of Bales' writings and the lobbying efforts of groups like Anti-Slavery International and Free the Slaves, the theme of modern slavery has been embraced by new generations of scholars and activists who identify as 'abolitionists'. Although abolitionism now focuses on contemporary ills, the language of abolition is also contested, not least because of its historic association with the transatlantic slave trade.

${ }^{3}$ See the Supplementary ILO Convention on the Abolition of Slavery, the Slave Trade and Practices, which was adopted in 1956 (ILO 1956). 
The abolitionists' emphasis on human rights, in particular the importance of human dignity within economic relations, has been challenged by critical scholars who emphasise enduring structural and power-based relations that foster extreme exploitation. The multiplicity of issues has complicated the development of an agreed discourse among academics on both what constitutes modern slavery and how it might be measured (O'Connell Davidson 2017); a challenge replicated in policy.

\section{DIFFERENTIATION IN LAW, PRACTICE, AND IMPLEMENTATION}

As modern slavery featured more prominently on both national and international agendas, important cracks appeared in the emerging regime. Research published by the UN University Centre for Policy Research (Gleason \& Cockayne 2018) found that both before and after the introduction of the UK Modern Slavery Act 2015, there has been marked variance in terms of how countries understand this phenomenon. One reason may lie with labelling and the use of language. When the General Assembly passed the Convention for the Suppression of the Traffic in Persons and of the Exploitation of the Prostitution of Others on 2 December 1949, the language of modern slavery was wholly undeveloped (UN 1949). Forced labour was penalised in some notable states, while it was simultaneously practised around the world. In fact, when the above convention entered into force, fewer than twenty countries had even ratified the 1932 ILO Convention Concerning Forced or Compulsory Labour. It took over three decades for commemoration of the day to be introduced, with the first International Day for the Abolition of Slavery held in 1986. Until then, the language of modern slavery largely preoccupied a small group of elite international civil servants.

In terms of state investment, we also find much differentiation. The ways in which states have directed their investment in this policy area indicate divergent policy priorities. Examining data over a fifteen-year period that pre-dates the modern slavery regime, Gleason and Cockayne (2018) consider how states understood their requirements in a host of related areas. Most notably they record a shift in funding from project aimed at curbing child labour to anti-trafficking efforts. There has also been little realisation of a body of jurisprudence in the area of international criminal law. As Duffy concludes, although slavery cases have been increasingly dealt with by regional courts, their 'jurisprudence remains remarkably limited in its volume and scope' (Duffy 2016: 400). She also notes that among the regional courts there were wide interpretations of modern slavery.

The lack of agreement over the scope and definition of modern slavery has also undermined the creation of a coherent body of human rights case law. We record, for 
example, that the European Court of Human Rights has been most interested in cases of forced labour, when they are, to a great extent, cases of a sexual nature. ${ }^{4}$ The InterAmerican Commission on Human Rights, by contrast has focussed on slavery in both commercial and military domains, ${ }^{5}$ while other regional courts have responded to less 'traditional' slavery cases, at least from a Global North view, hearing cases of, for example, 'chattel slavery'. 6

We have also witnessed multiple challenges to the implementation of both international and national legislation on modern slavery. As Vaughn et al. argue in this special issue, much compliance is based on limited information which primarily focuses on the first tier of suppliers, while lower tiers are more vulnerable to exploitative labour. Similarly, in their study on the effectiveness of the modern slavery reporting obligation enshrined in Article 54 of the UK Modern Slavery Act, Voss et al. (this issue) found that compliance approaches yield particularly limited results. While there is growing willingness on the part of businesses to comply with their legal requirements and publish transparency statements, capacity is often limited, especially as it regards remedying risks (see Rende Taylor \& Shih in this issue). Moreover, the quality, scope, depth, and regularity of reports are frequently compromised, especially since there are no meaningful sanctions for non-compliance.

One further point of contention is the degree to which governments sincerely wish to eradicate modern slavery. Nowhere is this more glaring than in Bangladesh, where the modern slavery regime was given an injection of energy, following the Rana Plaza tragedy of 2013. The collapse of this eight-storey building led to the Bangladesh Accord, a five-year, independent, legally binding agreement between global brands and retailers and trade unions designed to build a safe and healthy Bangladeshi readymade garment industry. However, even though the government has been keen to project the image of being committed to eradicating modern slavery, the industrial police has obstructed worker protests. Workers are not able to protest about wages or working conditions legally; as a result, throughout 2019 there has been widespread industrial unrest with nation-wide worker protests followed by massive worker dismissals in retaliation (Agence France Press 2019). While the UK has not experienced

\footnotetext{
${ }^{4}$ See Siliadin v. France, ECtHR (2006) App. No. 73316/01, 2005-VII. Kawogo v. United Kingdom, ECtHR (2010) App. No.56921/09. Rantsev v. Cyprus and Russia, ECtHR (2010) App. No. 25965/04. C.N \& V. v. France, ECtHR (2012) App. No.67724/09. M. and Others v. Italy and Bulgaria, ECtHR (2012) App. No.40020/03.

${ }^{5}$ See: Pereira v. Brazil, Petition 11.289 (IACtHR) Report No. 95/03, OEA/Ser.L/V/II.118, doc. 5 rev. 2 (2003). Vargas Areco v. Paraguay, IACtHR (2006) Ser. C No.155. Maya Indigenous People v. Guatemala, Petition 844-05 (IACtHR) Report No. 13/08, OEA/Ser.L/V/II.134, doc. 5 rev. 1 (2008). Hugo Maciel v. Paraguay, Case 11.607 (IACtHR) Report No. 85/09, OEA/Ser.L/V/II., doc. 51, corr. 1 (2009).

${ }^{6}$ See Hadijatou Mani Koroua v. Niger where the enslaved person was kept 'like a goat'. Mme Hadijatou Mani Koroua v. The Republic of Niger (No. ECW/CCJ/JUD/06/08), ECOWAS Court, October 2008.
} 
such unrest, the government's commitment to ending modern slavery was also called into question by the inability to replace the Independent Anti-Slavery Commissioner, a post which lay vacant for more than nine months.

Both law enforcement agencies and lawmakers have also challenged the UK government's commitment to eradicating modern slavery. In January 2019, a distinguished panel of parliamentarians published a damning report on the application of the Modern Slavery Act. This report evaluated the transparency in supply-chain provisions and laid out some frequently heard criticisms. One recurring issue has been the design and operation of the UK's modern slavery legislation. The authors found that there was uncertainty over which companies were covered by the legislation and condemned the level of reporting by firms as inadequate. They also identified poor compliance and identified a major weakness in the legislation, since large sectors of the economy, including public bodies, were exempt from the requirement to report on their own supply chains. The guiding conclusion from this report was that this legislation is far from sufficient to address the offences that fall under the UK Modern Slavery Act 2015.

The UK is, of course, far from alone. While states may be formally committed to the eradication of forced, compulsory, and child labour, as evidenced by the numbers of ratifications to the ILO instruments, there is a marked divide in practice. This includes uneven implementation of national laws and watered-down commitments. As noted elsewhere, slavery-type practices are frequently not treated as acts to be punished under criminal law; moreover, states often refrain from prosecuting such acts (Cockayne et al. 2016). Equally, we note that many workers themselves do not consider their conditions sufficiently appalling to warrant action; with some attributing their situation to bad luck or the function of structural hierarchies which they must endure. Such socio-culturally embedded traditional understandings may also undermine the effectiveness of the modern slavery regime.

One design challenge built into the Modern Slavery Act, and similar national legislation, is a tendency to pass on the obligation to eradicate modern slavery to the business sector without offering companies an incentive to comply with such obligations. While all business enterprises, regardless of their size, sector, location, ownership, or structure, are required to comply with all applicable laws and to respect human rights, both states and businesses have paid lip service to their legal obligations. There are many reasons for this, including the fact that the demand for businesses to comply with human rights requirements did not exist before the 1990s (Economist Intelligence Unit 2015). Yet, for scholars concerned to understand how the modern slavery legislation may be used to prevent abuse, such elusion in handling the issue is deeply problematic. Furthermore, even if most modern slavery abuses occur in the workplace, states should not sidestep their responsibilities to protect against human rights 
abuses by third parties, as affirmed in the UN Guiding Principles on Business and Human Rights (2011).

In addition, there are normative challenges which have undermined the establishment of a robust regime on modern slavery. One under-reported issue regards the purpose and methodologies used to evaluate the existing legislation and policy instruments. We note that, while many government departments rely increasingly on quantitative indicators to evaluate policy, the methodological tools made available to the modern slavery regime have yet to embrace scientific techniques. Few organisations have used systematic approaches to assess modern slavery in business, with a handful of notable exceptions that are still at an early stage of development. ${ }^{7}$ Again, the lack of incentives and the increasing demands on business to audit their activities may account for this situation.

\section{A FRAMEWORK FOR EVALUATING MODERN SLAVERY}

In the absence of robust evaluation, the failings associated with the dominant compliance approach to tackle modern slavery and associated human rights abuses are often excused on the basis of circumstance. Modern slavery occurs in an extraordinarily complex economic context in which global businesses operate, so we are told. While this is undoubtedly true, the emphasis on greater transparency and reporting remains insufficient. As others note, increased transparency alone is unlikely to improve working conditions or to address modern slavery unless it is accompanied by a focus on gaps in governance (McCall-Smith \& Rühmkorf 2017). Arguably, we cannot ignore the institutions and processes that frustrate the implementation of laws.

There are additional challenges and further consequences that may result from the preferred compliance model, not least shifting the burden of responsibility and in effect undermining the UN Guiding Principles. As Rende Taylor and Shih, as well as Deshingkar et al., argue in this issue, the audit-focussed approach downplays the critical intersection between the state and non-state actors and the ways in which the negligent or wrongful party may seek to avoid compliance with the law. Indeed, the design of the joint British Academy-DFID programme, 'Tackling Slavery, Human Trafficking and Child Labour', is squarely focussed on business practice - not government practice. Yet states are also responsible. In addition to the challenge of enforcement, which requires states to invest in people and infrastructure, scholars have condemned the role played by permissive and corrupt officials in the course activities which cross over into the business of modern slavery (see Deshingkar et al. in this issue).

${ }^{7}$ See Corporate Human Rights Benchmark (https://www.corporatebenchmark.org/§). 
For example, in the case of border guards and immigration officers who facilitate the flow of irregular migrants at risk of being trafficked, or the failure by government inspectors to report on factories and production centres where labour exploitation and associated offences takes place. Indeed, such challenges were foreseen in the 2014 ILO protocol, which demands that states introduce preventive measures such as 'labour inspection services' (or labour due diligences) in order to combat forced and compulsory labour both in private and public sectors of the economy (Article 2 (c) (ii)). Arguably, the prevalence of rigid social hierarchies which press individuals to accept intolerable conditions is also a factor, albeit an indirect one.

The question then arises: how can we realise the ambitions of the above international and national commitments to promote joint responsibility by states and the business sector? As established in the UN Guiding Principles, both are required to protect against human rights abuses and provide remedies where they have been violated. Taking responsibility seriously therefore means addressing the "wide and shocking' situation of non-enforcement (Cockayne et al. 2016: 254) and also understanding where that may both advance and undermine human rights claims. For example, as Deshingkar et al. argue in this issue, complicit officials, who violate the law and facilitate trafficking, are often not 'against' trafficked persons, but may be perceived as 'friends' who are helping desperately poor people into other livelihood situations.

While there are no easy answers, the articles in this issue propose some possible directions for future consideration by providing a deeper understanding of structural factors, not least the relationship between exploitation, economic development, and governance. This is critical to the creation and promotion of a culture of enforcement, as Cockayne et al. (2016) found:

The economic drivers of slavery intersect with political and social vulnerabilities: susceptibility to slavery is, unsurprisingly, correlated with socio-political marginalization and disenfranchisement. The demand for cheap labour intersects with individual vulnerability, often caused by poverty, domestic discrimination and conflict and displacement. Even those forms of slavery that seem particular to conflict, such as forced recruitment and use of children, seem to follow a similar cost-saving and industrial $\operatorname{logic}(256)$.

Arguably, understanding the points of intersection presents an invitation for further social scientific investigation.

We suggest that one starting point is to develop a critical understanding of the taxonomy of modern slavery offences in any given state. It is only by developing a deeper understanding of the types of state, modes of governance, and economic systems in which such offences occur, that we will arrive at suitable routes of intervention. Of course, states differ in their economic and industrial performance and we 
therefore need to take account of such particularities to identify where abuse is most likely to occur. Furthermore, not all sectors are the same - some are subject to greater oversight and regulation while others invite greater abuse than others. A critical investigation of modern slavery must therefore be context-specific. This includes an understanding of the scope and degree to which laws are in place and are enforceable. For example, as Pinheiro et al. argue in this volume, in spite of a law which criminalises modern slavery in Brazil, ineffective and fragmented law enforcement undermines its operation, deterring businesses from complying. We therefore recommend mapping existing legislation in order to identify potential avenues for redress, whether that is from anti-forced labour legislation, anti-trafficking laws, or newly introduced modern slavery legislation, and improved governance.

It is also essential to delineate areas of responsibility. To this end, we suggest mapping the ways in which people are affected against a typology of abuses ${ }^{8}$ and defined categories of perpetrators. We need to know which types of abuses are directed against which categories of people - and by whom. In the case of states, Webb and Garciandia (2019) suggest five principal ways in which states may be responsible. These include:

1. Direct enslavement by a state, that is, forcibly conscripting individuals: for example, in Uzbekistan to harvest cotton.

2. Indirect enslavement where state agents and recruiters place individuals in a situation of impossible debt.

3. Coercion - driven by societal, personal, and cultural expectations, as well as from situations of debt.

4. Structural factors which are poverty based; and include discrimination on the basis of gender and nationality.

5. Situations where individuals may elect to put themselves in abusive and exploitative situations.

The above factors may of course overlap.

Equally, when seeking practical remedies, it is important to consider where efforts should be concentrated. We note, for example, that states differ not only in the type of governmental regime but also in terms of the relationship with the non-state sector, which includes both business and civil society. Such practical realities should be considered in order to press for meaningful reform. Appendix 1 illustrates some of the political challenges which complicate the eradication of modern slavery and identifies areas where remedies may be sought.

${ }^{8}$ These include forced labour, bonded labour, forcibly trafficked persons, victims of extortion, and underpaid and indebted workers. 
The Appendix sheds light on the types of modern slavery offence studied in this issue, where they occur, and who is most affected by them. It also illustrates where development assistance might be used to enhance state capacity to tackle the issues associated with modern slavery: for example, by providing judicial training, or clarifying where both criminal and labour laws may be used to punish abuse (Beate 2016). Such abstract illustrations are complemented by further empirical research into the context in which modern slavery exists and in some cases flourishes.

For example, the article by Vaughn et al., which is based on qualitative data collected from workers in the 'fast fashion' garment industry of Bangladesh and Myanmar, presents various forms and extents of verbal, physical, psychological, sexual, and economic workplace violence and their numerous constellations. By showcasing the variegated exploitative experiences of workers and their families, it promotes the need to reconceptualise definitions of modern slavery along a spectrum with severe and less severe types and forms of exploitation at various ends (Skrivankova 2010).

Voss et al. (this issue) also explore the effectiveness of the MSA's reporting obligation. Following an analysis of publicly available transparency statements of supply chains in the fashion and textile sectors in terms of formal and content-related compliance, they have come to a similar conclusion to Vaughn et al., when stressing that tackling the issue of modern slavery primarily using the preferred compliance tool yields limited results. The growing willingness of businesses to comply with such legal requirements and publish transparency statements has been viewed by them as a positive sign, even though the quality, scope, depth, and regularity of the statements are frequently compromised, especially since they lack real sanctions for non-compliance. They argue, moreover, that the companies' over-reliance on media exposure of transparency statements has been instrumentalised by the state which has paid lip service to proper law enforcement mechanisms. Yet, the possibility of unsolicited media publicity may often act as a deterrent for businesses and could push them in the opposite direction: it can enhance non-compliance or highly restrained compliance. These findings reinforce the need for a diversity of multi-level, multi-form, and multi-actor approaches to address modern slavery and highlight the relevance of joint responsibility which demands equal commitment of the various actors.

Trafficking and physical coercion are often viewed as phenomena inextricably linked to modern slavery, particularly in the case of sex work. Cruz et al. (this issue) critically examine the boundaries between work, slavery, and freedom in an established Global North rhetoric. In particular, they argue that the way major legal instruments, such as the Victims of Trafficking and Violence Protection Act of 2000 in the United States and the Modern Slavery Act of 2015 in the United Kingdom, define trafficking and modern slavery 'fail to capture the realities, abuses, and needs' of their participants. They draw on data gained from narratives of sex workers in Jamaica, a country 
which is frequently presented as one deeply entangled in the web of 'trafficking' and 'modern slavery'. In the cases of their participants, physical coercion, as an inherent feature of discourses on sexual work, was often superseded by economic coercion driven by extreme poverty, especially at the entry stage to sex work. The authors thus call on us to pay attention to the underlying structural and socio-economic factors when inquiring into the junction of work, freedom, and trafficking.

In a similar vein to Cruz et al.'s article, Deshingkar et al.'s work (this issue) on precarious labour conditions of Ghanaians and Burmese migrants in the construction and domestic work sectors of Libya, the Middle East, Singapore, and Thailand also raises conceptual issues. Their study is another important contribution that interrogates some aspects of the migration industry in a culturally embedded way. By unsettling the widely held assumptions on the irreconcilable dialectics of migrants and brokers, together with the rhetoric of the benevolent state which is viewed as a positive actor, the article urges us to assume a less rigid, less compartmentalised approach to understanding modern slavery. Conditions of modern slavery arise with the concurrence, cooperation, and implications of the various actors of the regime, although at different levels and in different forms and depths. States, through their complicity, can be equally involved in the process, such as migrant workers who exercise agency. This article enables us to consider the fluid and contingent nature of the responsibility-action nexus, and in the meantime it urges us to think about responsibility in a holistic way.

The article by Pinheiro et al. (this issue) examines the nexus of laws tackling modern slavery, including human rights legislation, and the market characteristics of the Brazilian-UK beef and timber supply chains. The paper aims to explore to what extent multi-layered and overlapping norms and practices can contribute to business methods where human rights are respected. Unsurprisingly, ineffective and fragmented law enforcement creates a business environment where non-compliance with laws seem to be encouraged. Nevertheless, as the paper stresses, sector-specific characteristics leave significant footprints on business practices, including on exploitative ones. Although the article is written from a legal perspective, the recurring practice of ineffective law enforcement by the state has been raised in most of the contributions to this special issue. It foregrounds the role of responsibility by the state to enforce its national laws, as well as regional and international laws to which it adheres. At the same time, there is a clear responsibility on businesses, including transnational ones with part of their supply chains in Brazil, to abide by laws that address them, even in the event of a weaker institutional compliance control. As the article highlights, a more concerted approach would be needed to eradicate labour law exploitation with stronger enforcement and monitoring. This latter might be done increasingly with the use of technology, as businesses' compliance with human rights is more difficult to supervise when exploitative labour takes place in remote areas. 
The potential of technologies - in particular mobile-phone-based tools and applications - to combat modern slavery in global supply chains is reviewed by Rende Taylor and Shih (this issue). It is assumed that, since businesses are better placed to identify and remediate modern slavery conditions with the use of technologies that enable worker feedback, they would take greater responsibility in combating modern-day slavery. Their article, however, paints a darker picture by shedding light on significantly lesser ambitions and practices of corporations, where corporations are primarily interested in promoting due diligence, rather than remediation.

The authors demonstrate that due diligence tools, developed and sold to businesses by for-profit tech companies, are used primarily by businesses to identify human trafficking and forced labour within their supply chains but not to address it. They argue that these tools are purposefully designed to have limited scope and not reveal, in earnest, serious modern slavery issues, mainly for lack of willingness and capacity on the side of businesses to deal with and to remedy such risks. Hence, these technologies seem to be the perfect tools to 'produce deliverables', which are so much needed for compliance. On the other hand, remediation tools are usually developed and/or primarily used by non-profit entities, such as civil society and human rights enhancing organisations, with the aim of identifying and addressing issues of modern slavery. The article calls for reconsidering the sole use of due diligence tech tools by transnational companies. Instead, they advocate for the need for businesses to employ more remediation tech tools with real remediation potential. The intended use of these technological methods allows us to ponder on the recurring theme of conflicting responsibilities in the fight against modern slavery. Are businesses solely responsible for the wide use of the more formulaic and, from a business risk perspective, safer due diligence process? The authors infer that companies would probably be more prepared to do more than basic legal compliance if real options for them were available to remedy modern slavery conditions within their supply chain.

In the last article of this collection, Jones et al. (this issue) raise the issue of moral and ethical responsibility of transnational businesses in combating and remedying forced labour within their supply chains. They do so by investigating poor working conditions of Indonesian fishermen within the domestic labour market, situated at the axis of the state and global fish market. Their study identifies a high degree of informality within the sector and the extensive reliance on existing social networks, especially in the case of smaller fishing vessels. These attributes manifest themselves mainly in recruitment practices, in the pervasive lack of written employment agreements, but also in terms of on-board workshare and discipline procedures. Importantly, these also have an impact on payment conditions, which are closely linked to (temporary) bonded labour. 
The authors invite transnational businesses in the global fish for food sector to reconsider their responsible sourcing approaches in relation to their sourcing from Indonesian supply chains. In particular, as they state, hitherto not enough attention has been given to potential forced labour conditions experienced by domestic workers within the Indonesian fishing industry, whilst exploitation of migrant workers, especially on Thai and Taiwanese shipping vessels, has received widespread media scrutiny. According to them, these may be related to ill-seated assumptions linked to the structure and small-scale fishing methods of the Indonesian fishing sector, which make transnational companies unaware of and reluctant to investigate potential labour risks. Scarcity in the availability of worker's voices and lack of organisations that could effectively represent workers' interests may also add to such business practice. The authors warn us that, in the absence of responsible sourcing practices of transnational businesses, the business risks continue to rest jointly on local companies and workers, while human rights risks would always be allocated to the fishing crew.

\section{CONCLUSION}

The contributions to this special issue highlight the complex nature of the modern slavery regime and also the value of joint, as well as individual, responsibility in combatting modern-day slavery. Whilst profound power imbalances exist between the state, businesses, and workers, all play their part in tackling the issue. A central problem remains the governance of modern slavery. It is still early days and, as noted above, the challenges of implementation and commitment on the part of states and businesses undermine effective enforcement of human rights norms. However, reform follows analysis and criticism. By illustrating where action has proven successful, and why poor governance allows abuse to flourish, the articles in this issue provide a rare insight into the operations of the modern slavery regime in an international and comparative context. Most importantly, they demonstrate how empirically grounded research may advance our understanding of emerging global discourses on modern slavery and shine a light on promising practices that incentivise action to tackle abuse and exploitation. 


\section{REFERENCES}

African Charter on Human and Peoples' Rights (1987). http://www.achpr.org/instruments/achpr/

Agence France Presse (2019), 'Bangladesh Strikes: Thousands of Garment Workers Clash With Police

Over Poor Pay', The Guardian, 14 January.

https://www.theguardian.com/world/2019/jan/14/bangladesh-strikes-thousands-of-garment-workers-clash-withpolice-over-poor-pay

American Convention on Human Rights (1969). https://www.refworld.org/docid/3ae6b36510.html

Bales, Kevin (1999), Disposable People: New Slavery in the Global Economy (Berkeley, CA, University of California Press).

Bassiouni, C. M. (1998), 'International Crimes: Jus cogens and obligatio erga omnes', Law and Contemporary Problems, 59: 63-74. https://doi.org/10.2307/1192190

Beate, Andrees (2016), 'Defending Rights, Securing Justice, The International Labour Organization's Work on Forced Labour', Journal of International Criminal Justice, 14: 343-62. https://doi.org/10.1093/jicj/mqw018

Bloomfield, M. \& LeBaron, G. (2018), 'The UK Modern Slavery Act: Transparency through Disclosure in Global Governance', E-International Relations.

https://www.e-ir.info/2018/09/21/the-uk-modern-slavery-act-transparency-through-disclosure-inglobal-governance/.

California Transparency in Supply Chains Act (2010) SB657.

http://www.state.gov/documents/organization/164934.pdf

Cockayne, J., Grono, N. \& Panaccione, K. (2016), 'Introduction', Special Issue: Slavery and the Limits of International Criminal Justice, Journal of International Criminal Justice, 14: 253-67. https://doi.org/10.1093/jicj/mqw014

Corrie, K. L. (2016), 'Could the International Criminal Court Strategically Prosecute Modern Day Slavery?’ Journal of International Criminal Justice, 14: 285-303. https://doi.org/10.1093/jicj/mqv064

Council of Europe (2005), Council of Europe Convention on Action against Trafficking in Human Beings, https://ec.europa.eu/anti-trafficking/sites/antitrafficking/files/cets_197.docx.pdf

Cruz, Katie, O'Connell Davidson, Julia \& Sanchez Taylor, Jacqueline (2019), 'Tourism and Sexual Violence and Exploitation in Jamaica: Contesting the "Trafficking And Modern Slavery" Frame', Journal of the British Academy, 7(s1): 191-216. https://doi.org/10.85871/jba/007s1.191

Deshingkar, Priya, Awumbila, Mariama \& Teye, Joseph Kofi (2019), 'Victims of Trafficking and Modern Slavery or Agents of Change? Migrants, Brokers, and the State in Ghana and Myanmar', Journal of the British Academy, 7(s1): 77-106. https://doi.org/10.85871/jba/007s1.077

Duffy, H. (2016), 'Litigating Modern Day Slavery in Regional Courts: A Nascent Contribution', Special Issue: Slavery and the Limits of International Criminal Justice, Journal of International Criminal Justice, 14: 375-403. https://doi.org/10.1093/jicj/mqv079

Economist Intelligence Unit (2015) The Road from Principles to Practices: Today's Challenges for Business in Respecting Human Rights', 13 October.

https://www.eiuperspectives.economist.com/strategy-leadership/road-principles-practice

EU (2011), Directive 2011/36/EU of the European Parliament and of the Council of 5 April 2011 on Preventing and Combating Trafficking in Human Beings and Protecting its Victims, and Replacing Council Framework Decision 2002/629/JHA.

https://eur-lex.europa.eu/legal-content/en/TXT/?uri=CELEX\%3A32011L0036

European Convention for the Protection of Human Rights and Fundamental Freedoms (1950).

https://www.echr.coe.int/Documents/Convention_ENG.pdf 
Freedom United (2019), 'Field Report: Modern Slavery in UN Sustainable Development Goals. Freedom United'.

https://www.freedomunited.org/our-impact/slavery-sustainable-development-goals-2/ [accessed 13 March 2019].

Gleason, Kelly A. \& Cockayne, James (2018), 'Official Development Assistance and SDG Target 8.7', Centre for Policy Research, United Nations University.

http://collections.unu.edu/view/UNU:6612\#viewAttachments

Haynes, J. (2016), 'The Modern Slavery Act (2015): A Legislative Commentary', Statute Law Review, 37(1): 33-56. https://doi.org/10.1093/slr/hmv024

ILO (1930), Convention Concerning Forced or Compulsory Labour (C029), International Labour Organization. https://www.ilo.org/dyn/normlex/en/f?p=NORMLEXPUB:12100:0::NO::P12100_ILO_CODE:C029

ILO (1956), Supplementary Convention on the Abolition of Slavery, the Slave Trade, and Institutions and Practices Similar to Slavery, International Labour Organization.

http://www.un.org/en/genocideprevention/documents/atrocity-crimes/Doc.15_supplementary\% 20slaverytrade.pdf

ILO (1957), Abolition of Forced Labour Convention (C105), International Labour Organization. https://www.ilo.org/dyn/normlex/en/f?p=1000:12100:0::NO::P12100_ILO_CODE:C105

ILO (1998), Declaration on Fundamental Principles and Rights at Work, International Labour Organization. https://www.ilo.org/declaration/thedeclaration/textdeclaration/lang--en/index.htm

ILO (1999), Worst Forms of Child Labour Convention (C182), International Labour Organization. https://www.ilo.org/dyn/normlex/en/f?p=NORMLEXPUB:12100:0::NO::P12100_ILO_CODE:C182

ILO (2014), Protocol of 2014 to the Forced Labour Convention, 1930 (P029), International Labour Organization.

https://www.ilo.org/dyn/normlex/en/f?p=NORMLEXPUB:12100:0::NO::P12100_ILO_CODE:P029

International Covenant on Civil and Political Rights (1966). https://www.ohchr.org/en/professionalinterest/pages/ccpr.aspx

Jones, Katharine, Visser, David \& Simic, Agnes (2019), 'Fishing for Export: Calo, Recruiters, Informality, and Debt in International Supply Chains', Journal of the British Academy, 7(s1): 107-130. https://doi.org/10.85871/jba/007s1.107

Krasner, S. D. (1982), 'Structural Causes and Regime Consequences: Regimes as Intervening Variables', International Organization, 36(2): 185-205. .https://doi.org/10.1017/S0020818300018920

McCall-Smith, K. \& Rühmkorf, A. (2018), 'Reconciling Human Rights and Supply Chain Management through Corporate Social Responsibility', in V. Ruiz Abou-Nigm, K. McCall-Smith \& D. French (eds.), Linkages and Boundaries in Private and Public International Law. (Oxford, Hart), 147-73.

Modern Slavery Act 2015. (c.30) (London, The Stationery Office). http://www.legislation.gov.uk/ukpga/2015/30/contents/enacted

O'Connell Davidson, J. (2017), 'Editorial: The Presence of the Past: Lessons of History for Antitrafficking Work', in Special Issue: The Lessons of History, Anti-Trafficking Review, (9):1-13. https://doi.org/10.14197/atr.20121791

Pinheiro, Silvia Marina, Emberson, Caroline \& Trautrims, Alexander (2019), " For the English to See" or Effective Change? How Supply Chains Are Shaped by Laws and Regulations, and What That Means for the Exposure of Modern Slavery', Journal of the British Academy, 7(s1): 167-190. https://doi.org/10.85871/jba/007s1.167

bin Ra'ad Al Hussein, Z. (2015), 'Ethical Pursuit of Prosperity', The Law Society Gazette, 23 March 2015.

http://www.lawgazette.co.uk/analysis/comment-and-opinion/ethical-pursuit-of-prosperity/5047796. fullarticle 
Rende Taylor, Lisa \& Shih, Elena (2019), 'Worker Feedback Technologies and Combatting Modern Slavery in Global Supply Chains: Examining the Effectiveness of Remediation-oriented and Duediligence-oriented Technologies in Identifying and Addressing Forced Labour and Human Trafficking', Journal of the British Academy, 7(s1): 131-165.

https://doi.org/10.85871/jba/007s1.131

Ruggie, J. G. (2017), 'The Social Construction of the UN Guiding Principles on Business and Human Rights', Corporate Responsibility Initiative Working Paper No. 67, John F. Kennedy School of Government, Harvard University, Cambridge, MA. https://doi.org/10.2139/ssrn.2984901

Skrivankova, K. (2010), 'Between Decent Work and Forced Labour: Examining the Continuum of Exploitation', Joseph Rowntree Foundation.

https://www.jrf.org.uk/report/between-decent-work-and-forced-labour- examining-continuumexploitation

UN (1949), Convention for the Suppression of the Traffic in Persons and of the Exploitation of the Prostitution of Others. https://www.ohchr.org/EN/ProfessionalInterest/Pages/TrafficInPersons.aspx

UN (1989), Convention on the Rights of the Child.

https://www.ohchr.org/en/professionalinterest/pages/crc.aspx

UN (2000), Protocol to Prevent, Suppress and Punish Trafficking in Persons Especially Women and Children, Supplementing the United Nations Convention Against Transnational Organized Crime. https://www.ohchr.org/en/ProfessionalInterest/Pages/ProtocolTraffickingInPersons.aspx

UN (2011), UN Guiding Principles on Business and Human Rights. Implementing the United Nations 'Protect, Respect and Remedy' Framework. (New York and Geneva, United Nations Publications). https://www.ohchr.org/Documents/Publications/GuidingPrinciplesBusinessHR_EN.pdf

UN (2015), 'Transforming Our World: The 2030 Agenda For Sustainable Development', A/RES/70/1. https://sustainabledevelopment.un.org/content/documents/21252030 $\% 20$ Agenda $\% 20$ for $\% 20$ Sustainable \%20Development $\% 20$ web.pdf

Van der Wilt, H. (2016), 'Slavery Prosecutions in International Criminal Jurisdictions', Journal of International Criminal Justice, 14: 269-83. https://doi.org/10.1093/jicj/mqv071

Vaughn, Leona, Balch, Alex, Johns, Jennifer \& Currie, Samantha (2019), 'Transparency in Supply Chains and the Lived Experiences of Workers and Their Families in the Garment Sectors of Bangladesh And Myanmar', Journal of the British Academy, 7(s1): 35-60. https://doi.org/10.85871/jba/007s1.035

Verdross, A. (1966), 'Jus dispositivum and jus cogens in International Law', American Journal of International Law, 60: 58-9. https://doi.org/10.2307/2196718

Victims of Trafficking and Violence Protection Act of 2000. https://www.state.gov/j/tip/laws/61124.htm

Voss, Hinrich, Davis, Matthew, Sumner, Mark, Waite, Louise, Ras, Ilse A., Singal, Divya \& Jog, Deepti (2019), 'International Supply Chains: Compliance and Engagement with the Modern Slavery Act', Journal of the British Academy, 7(s1): 61-76. https://doi.org/10.85871/jba/007s1.061

Webb, P. \& Garciandia, R. (2019), 'State Responsibility for Modern Slavery: Uncovering and Bridging the Gap'.

https://www.thebritishacademy.ac.uk/sites/default/files/State-responsibility-for-modern-slaveryWebb-Garciandia.pdf.

\section{Notes on the authors}

Agnes Simic is a former Hungarian solicitor turned into social policy researcher in the area of migration. She is currently a research officer at the Institute of Global Affairs of the London School of Economics and Political Science. She had worked as a research assistant on numerous migration-related research projects at the LSE, the 
University of Exeter, and Middlesex University. One of her recent research projects focussed on legal and procedural information provision to asylum seekers in the UK and in Hungary. Agnes has held lectures and seminars at the Department of Criminology and Sociology of Middlesex University, where she is currently an hourlypaid lecturer in Migration and Citizenship.

a.simic@mdx.ac.uk or agnes.simic@outlook.com

\section{Recent publications:}

'Subversive Citizens: Using EU Free Movement Law to Bypass The UK's Rules on Marriage Migration' (with Helena Wray \& Eleonore Kofman), Journal of Ethnic and Migration Studies, Special Issue (forthcoming 2019, accepted).

'INFORM: Legal and procedural information for asylum seekers in the European Union. Hungary Country Report (with Zoltán Barcza-Szabó, Gruśa Matevžič, Zoltán Somogyvári \& Zsolt Szekeres), (2018).

https://www.inform-asylum.eu/uploads/1/2/1/7/12176018/midj6040_middlesex-uni-hungary180712.pdf

'INFORM: Legal and Procedural Information for Asylum Seekers in the European Union', UK Country Report (with Jocelyn Hutton \& Brad Blitz), (2018).

https://www.inform-asylum.eu/uploads/1/2/1/7/12176018/midj6040-report-uk-180416-8-web.pdf

Brad K. Blitz is Director of the British Academy/DFID Programme, 'Tackling Slavery, Human Trafficking and Child Labour in Modern Business', and has recently been appointed Professor of International Politics and Policy at University College London Institute of Education. He is also Visiting Professor at the London School of Economics, and Senior Fellow of the Global Migration Centre in the Graduate Institute, Geneva.

He recently acted as Principal Investigator for the ESRC-DFID funded EVI-MED project on refugee and migrant reception systems in the Mediterranean and the EU Commission project INFORM, which seeks to understand how asylum seekers access legal and procedural information. In March 2019 he began a five-year project as co-investigator of a $£ 17.4$ million 'hub' on Gender, Justice and Security, funded by the Global Challenges Research Fund (GCRF) with the London School of Economics.

Publications include Statelessness in the European Union: Displaced, Undocumented and Unwanted (Cambridge University Press, 2011) and Statelessness and Citizenship: A Comparative Study on the Benefits of Nationality (Edward Elgar, 2011). In 2011, he completed a US State Department funded project 'Measuring the Costs of Statelessness', which subsequently informed US humanitarian policy. He also contributed to UNDP's Asia-Pacific Human Development Report. In November 2013, he completed a major cross-national study of the benefits of birth registration on development outcomes for Plan International. He is also the author of Migration and 
Freedom: Mobility, Citizenship, and Exclusion (Edward Elgar, 2014; reissued in 2016), which was nominated for three awards.

brad_blitz@yahoo.com

To cite the article: Agnes Simic and Brad K. Blitz (2019), 'The modern slavery regime: a critical evaluation', Journal of the British Academy, 7(s1): 1-34.

DOI https://doi.org/10.5871/jba/007s1.001

This article is licensed under a

Creative Commons Attribution-NonCommercial-NoDerivs 4.0 Unported License.

Journal of the British Academy (ISSN 2052-7217) is published by

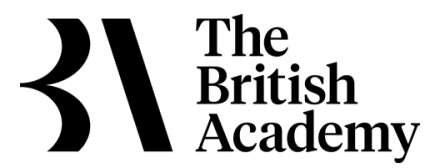

10-11 Carlton House Terrace, London, SW1Y 5AH

www.thebritishacademy.ac.uk 


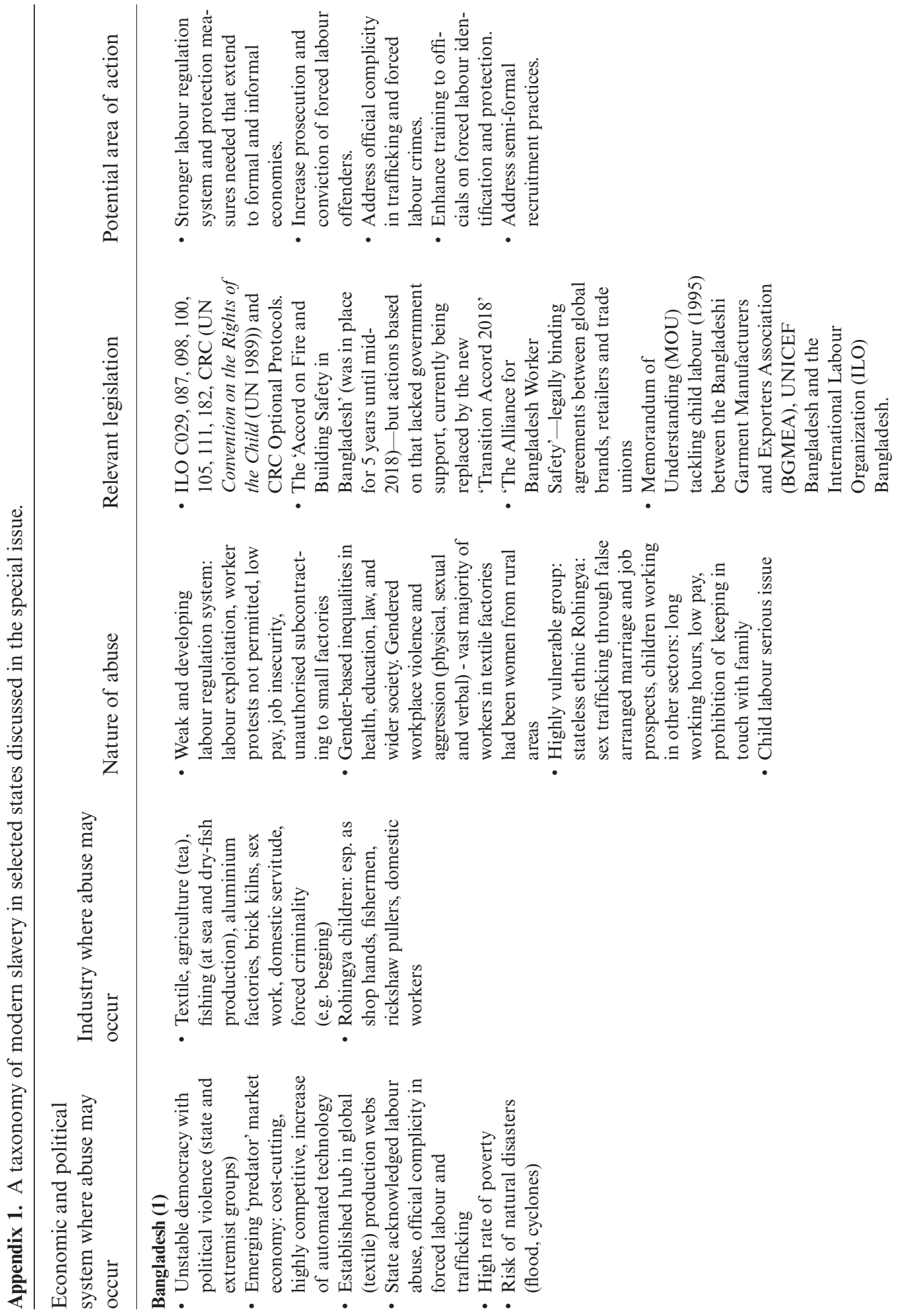




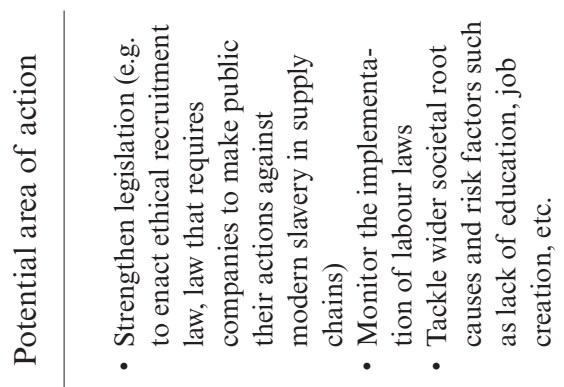

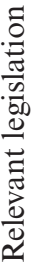

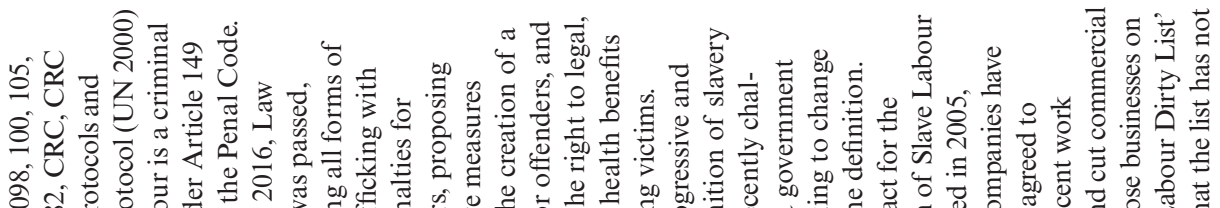

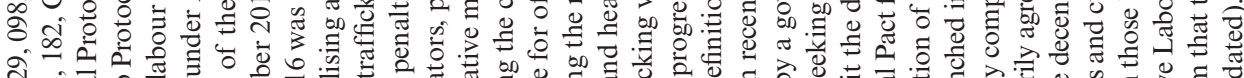

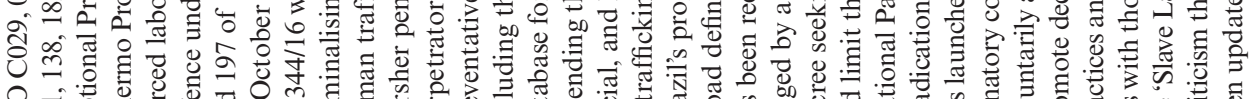

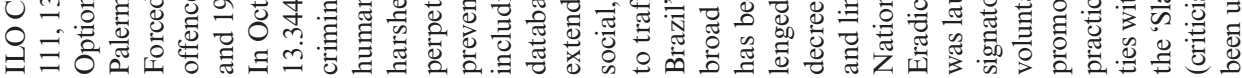

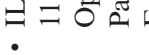

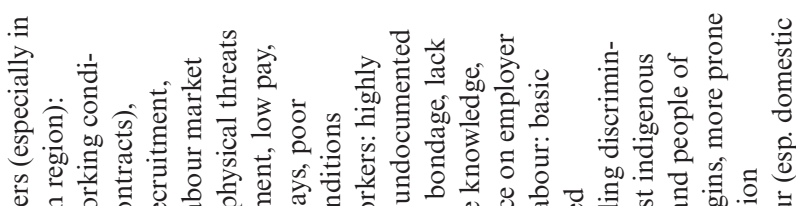

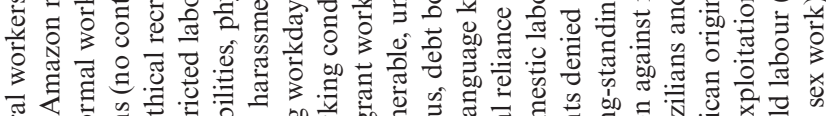

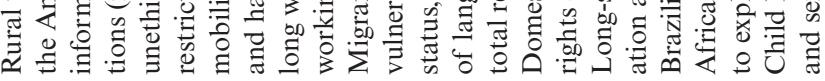

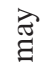

$\stackrel{\mathscr{E}}{0}$ 


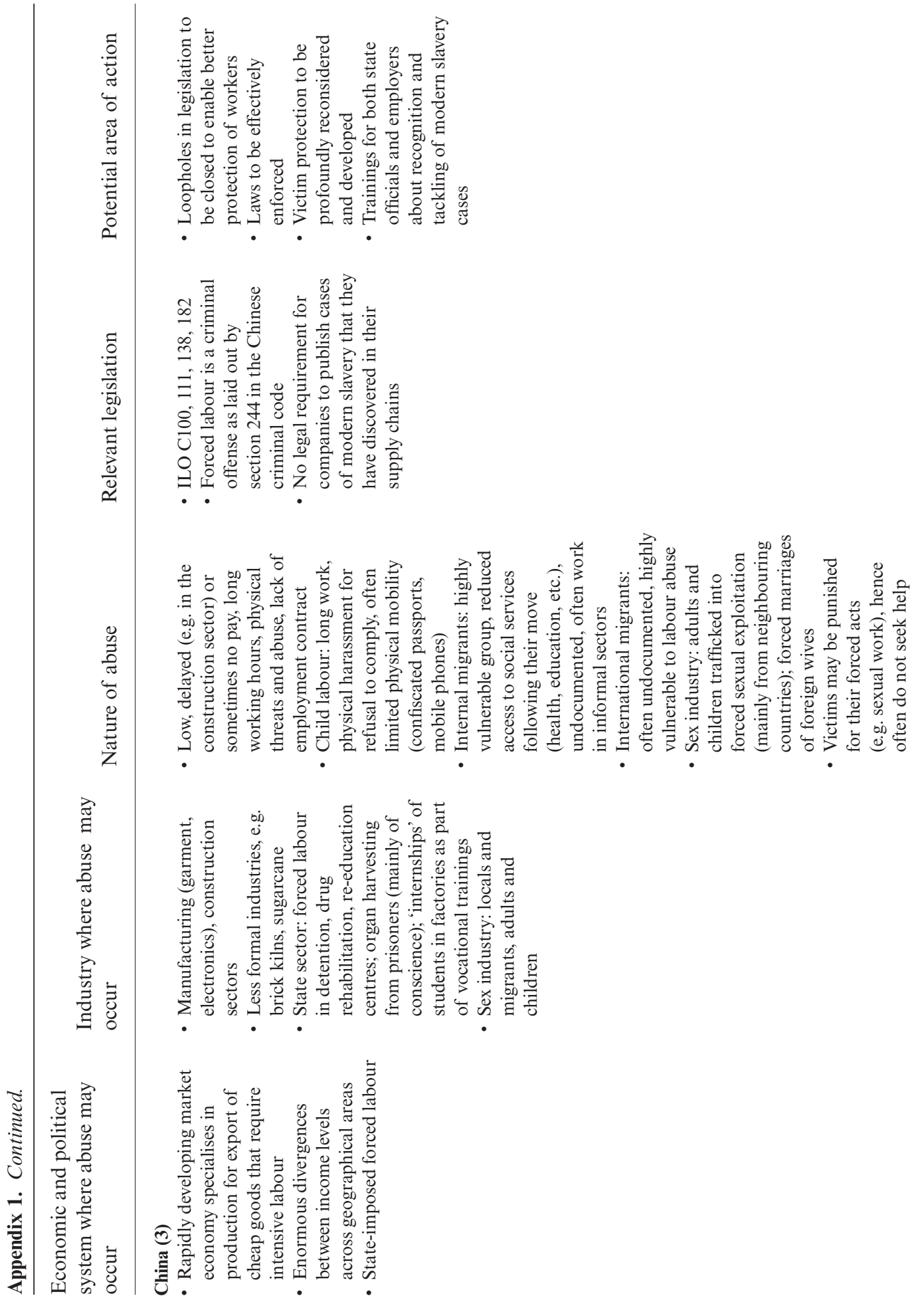




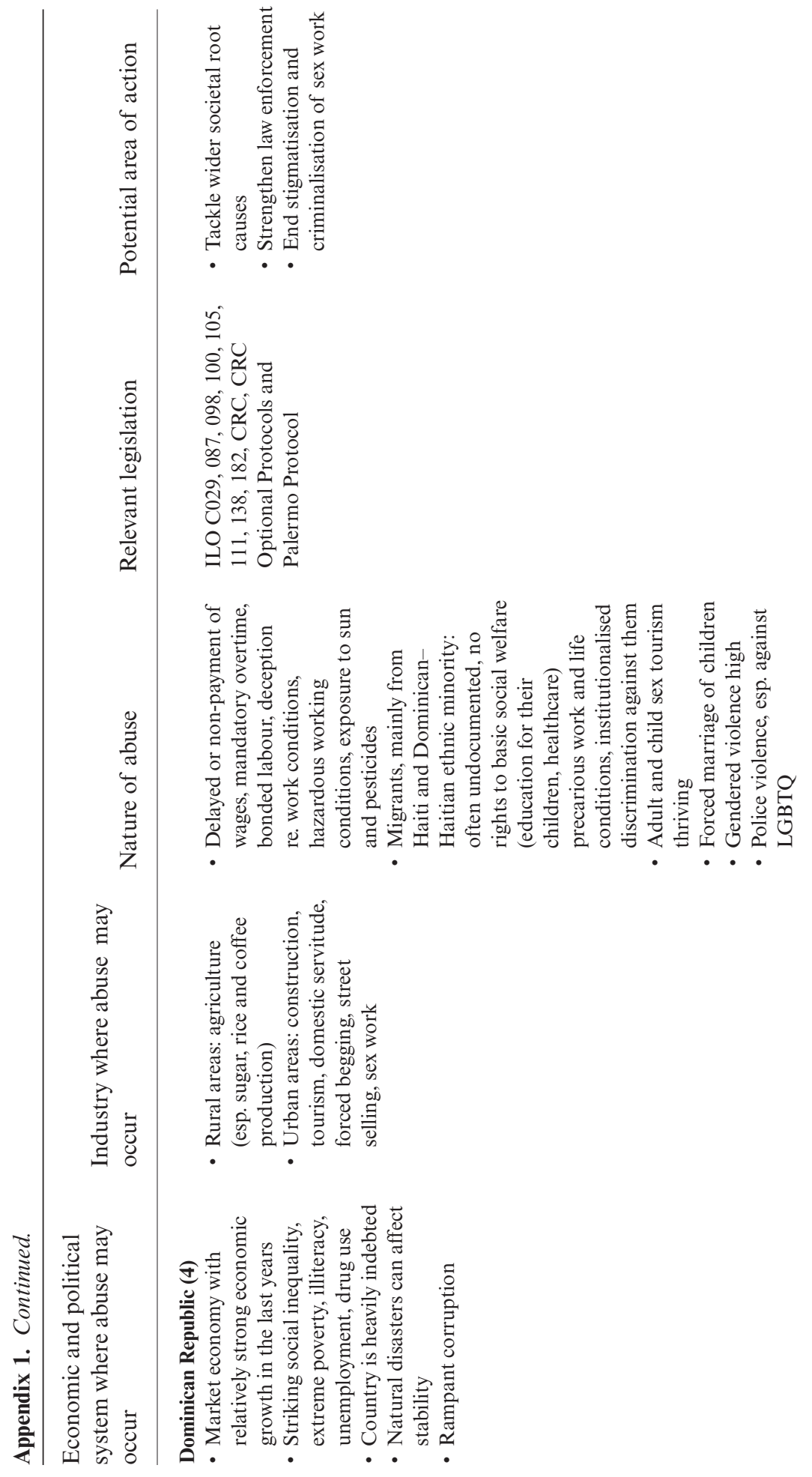




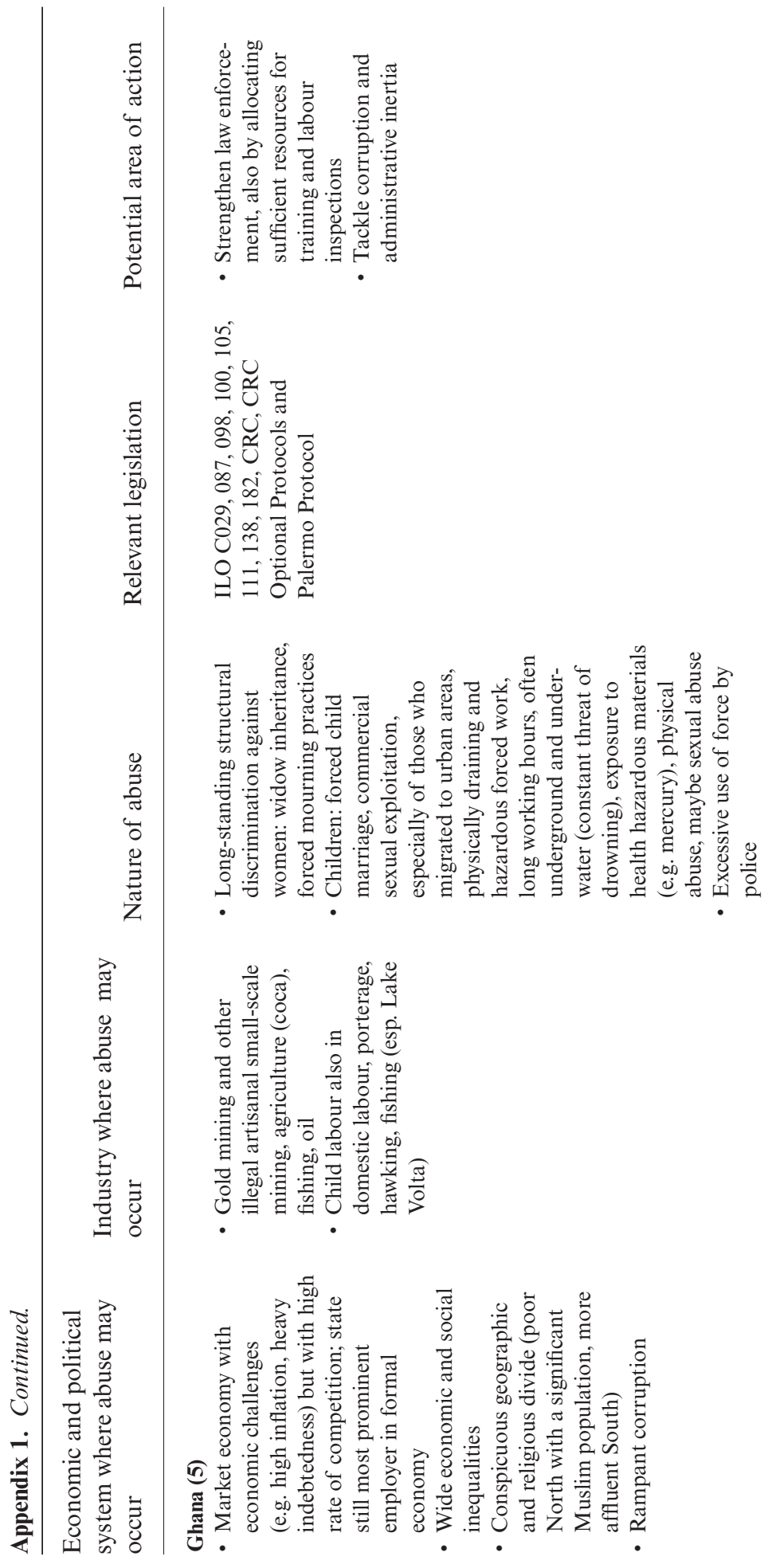




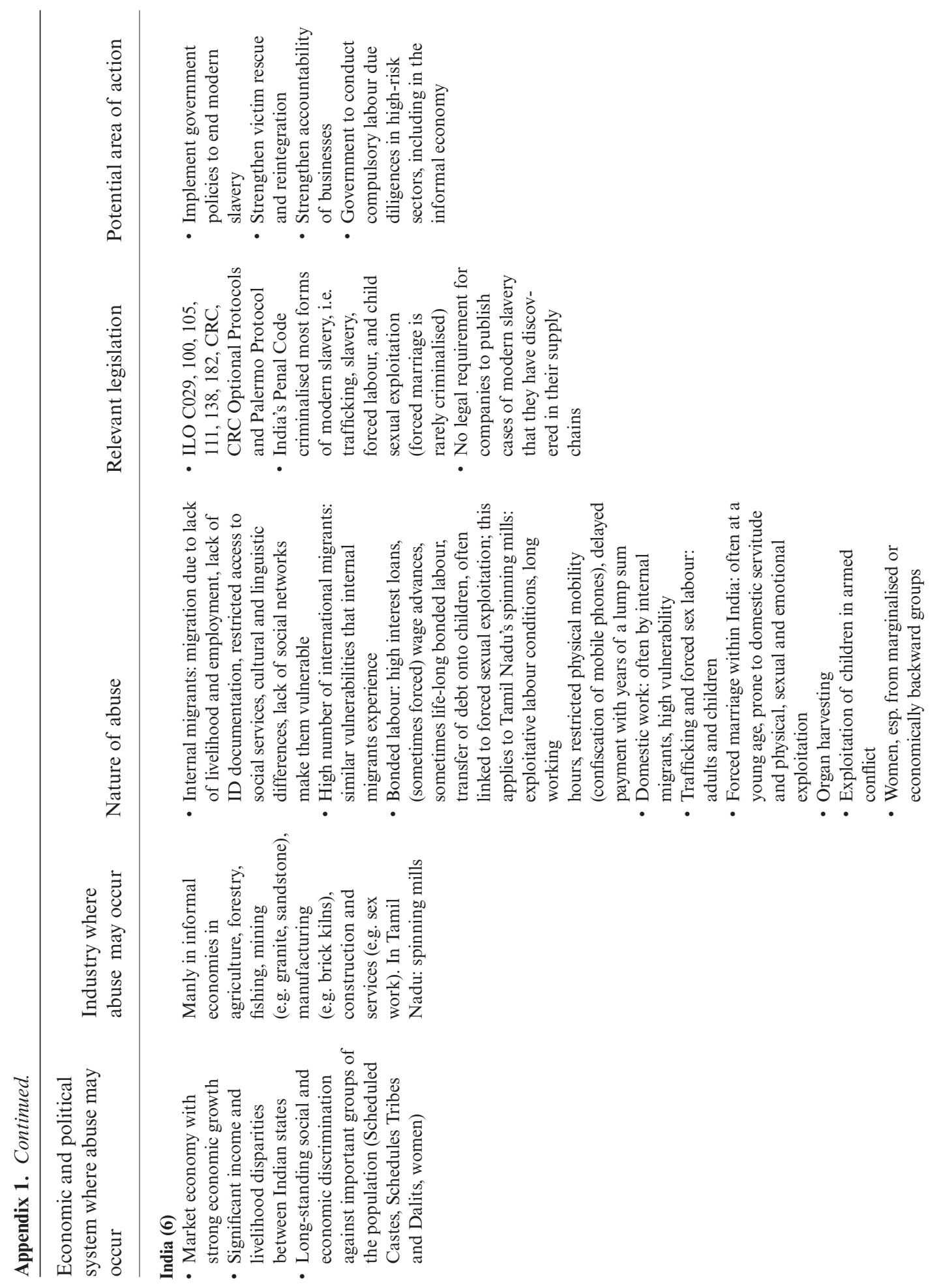




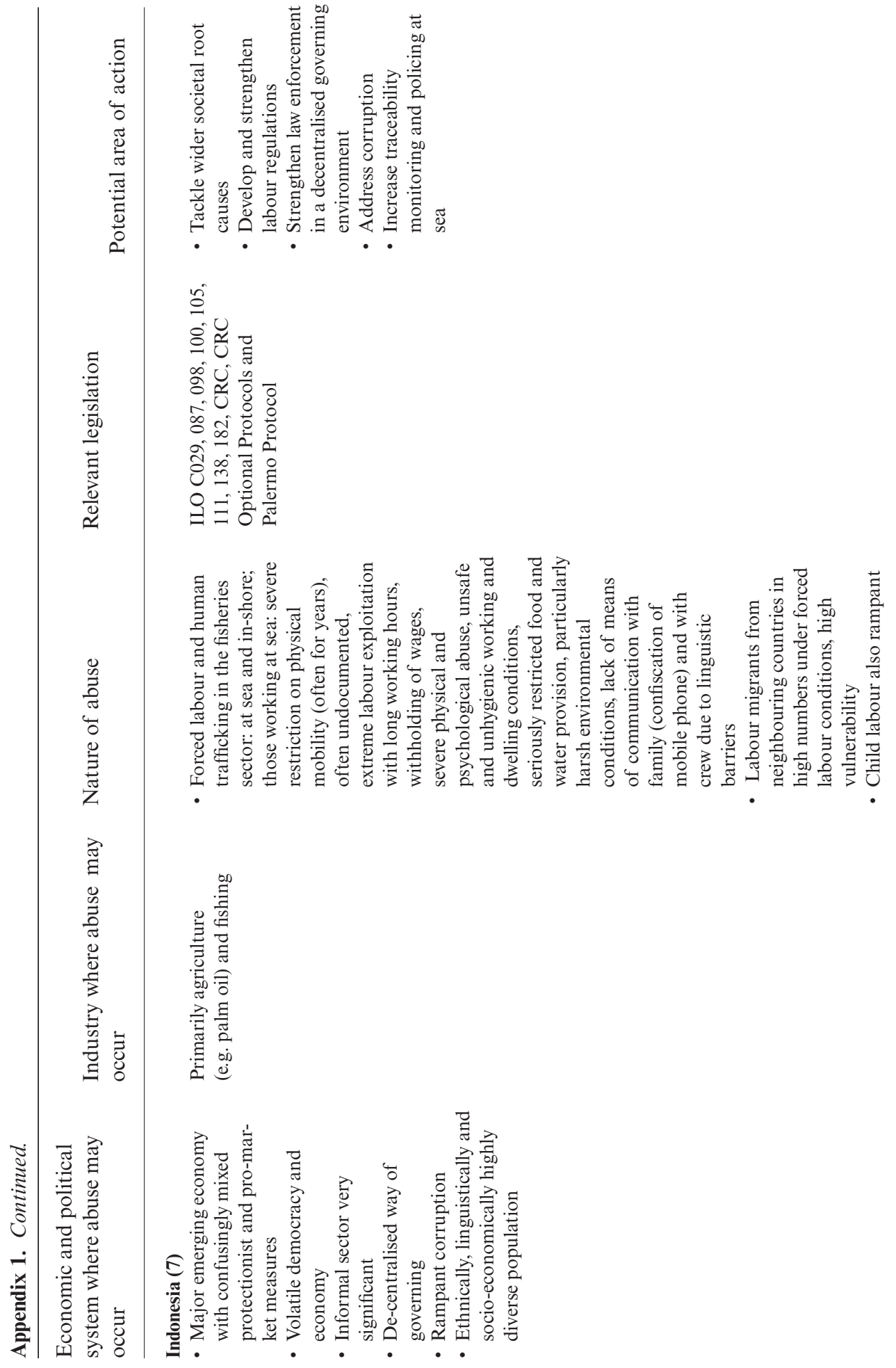




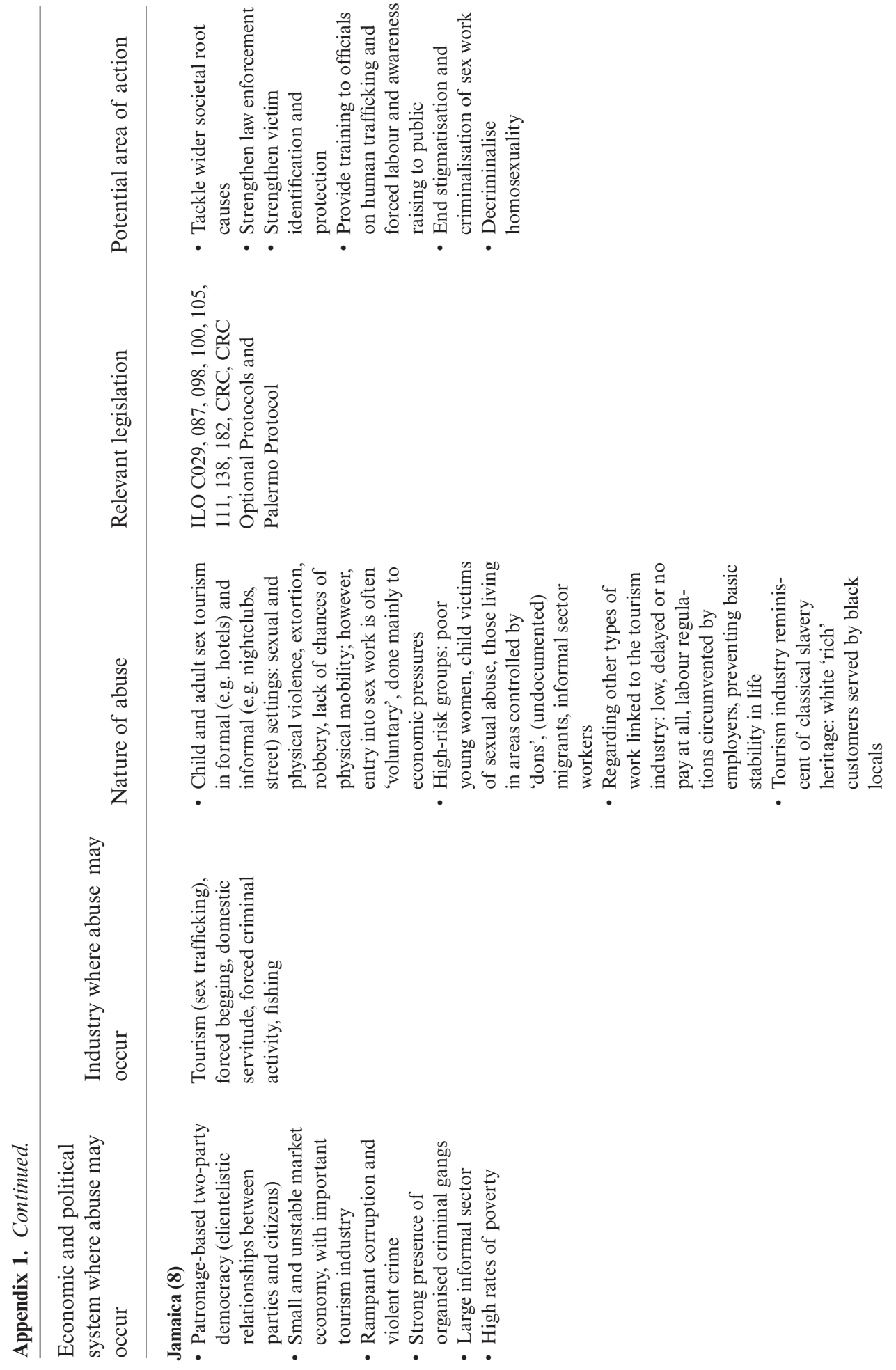




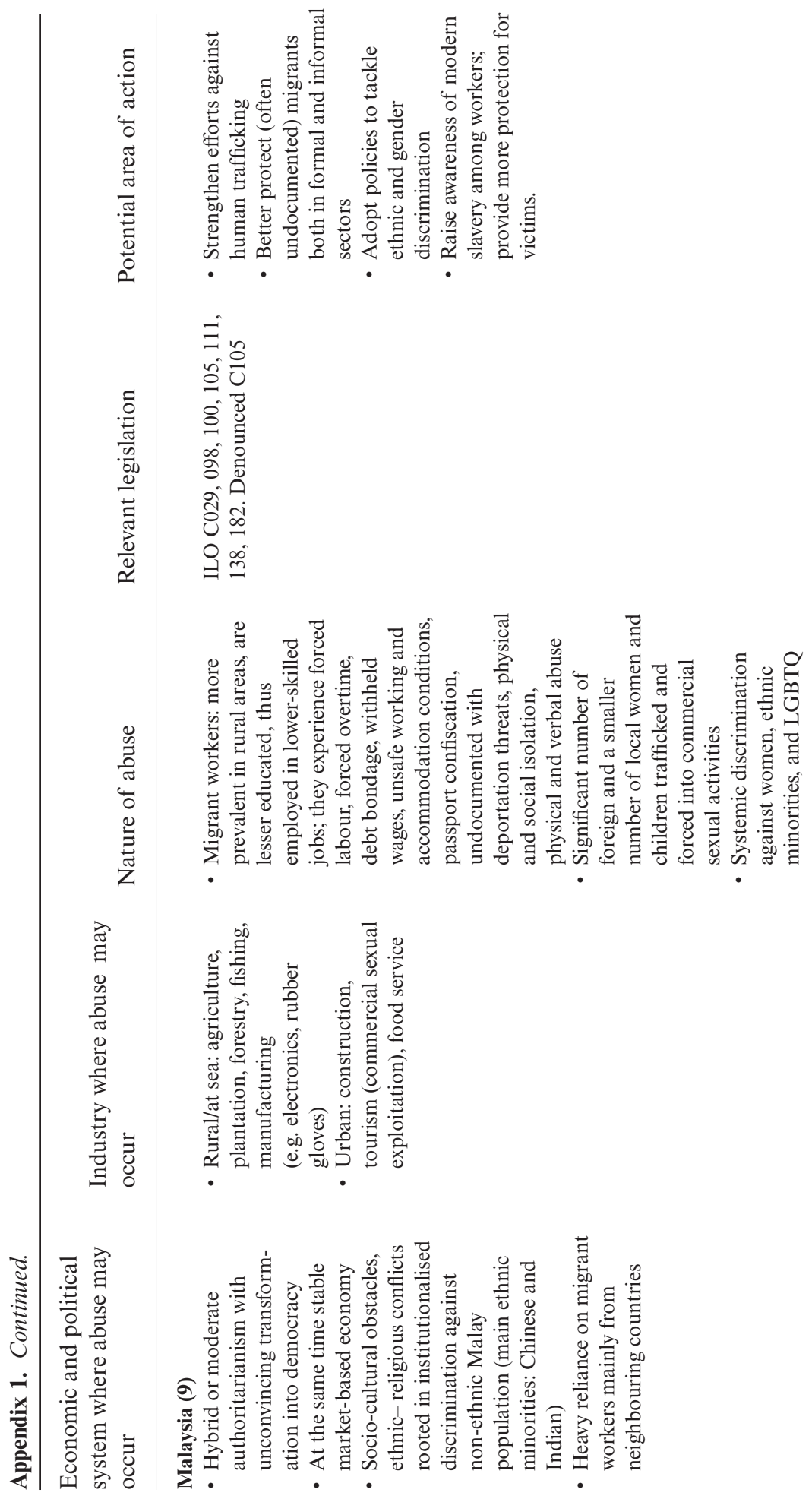



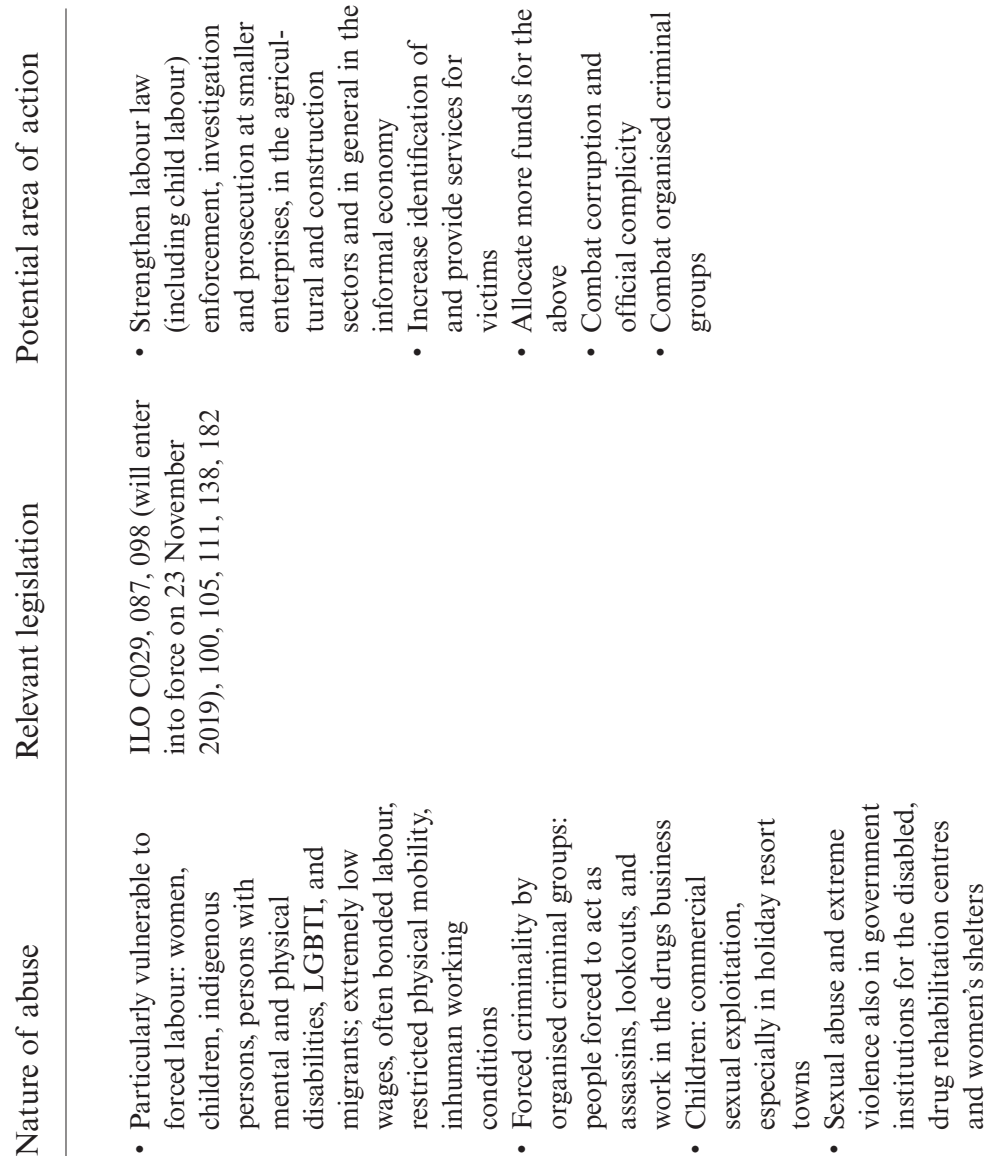

帘

莡

$\frac{\grave{5}}{3}$

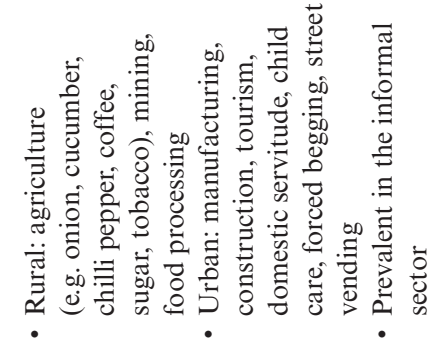

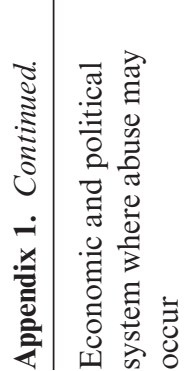

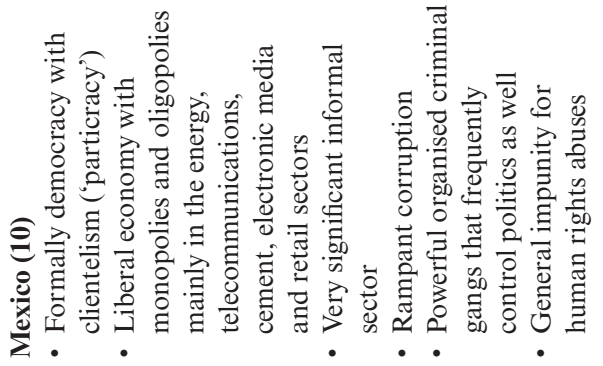




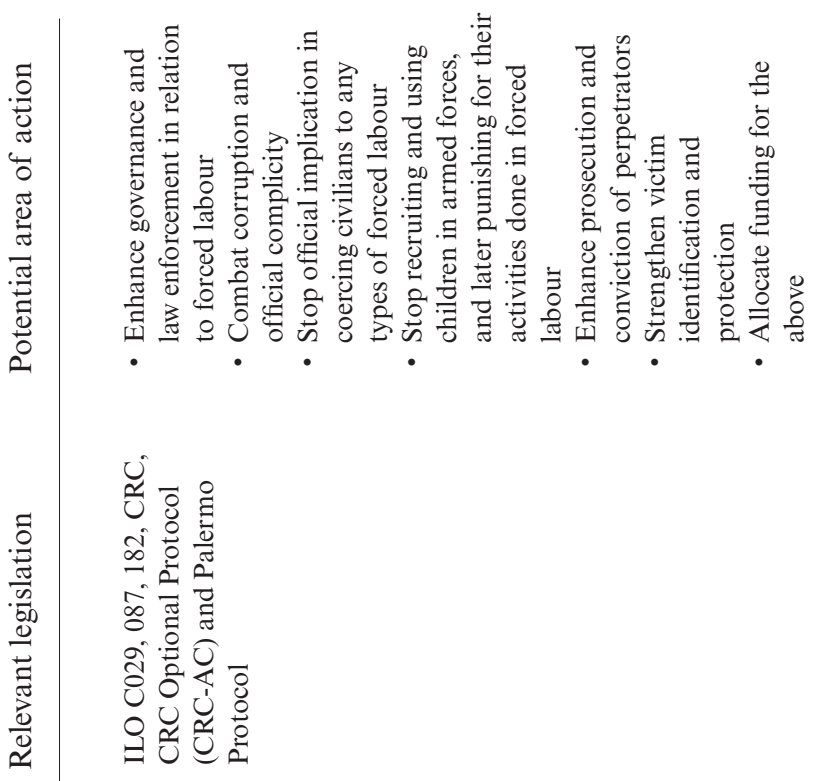

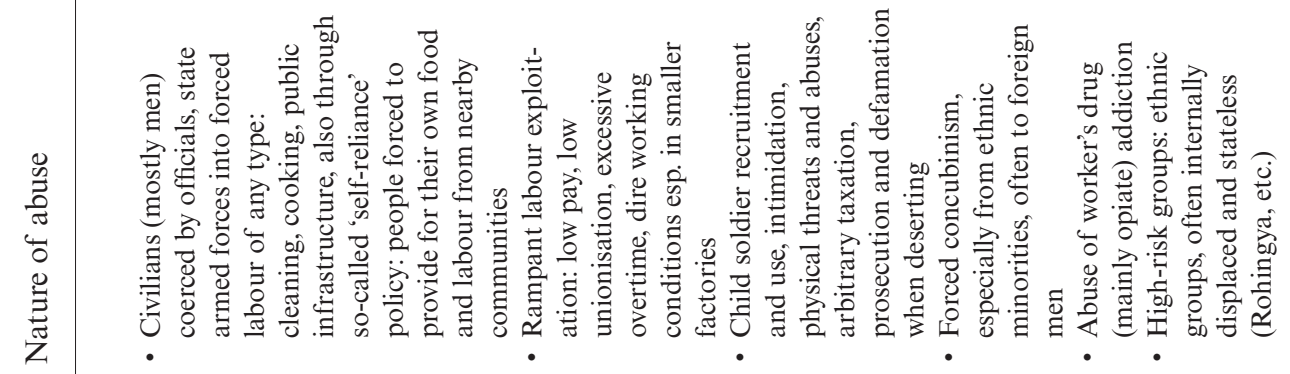

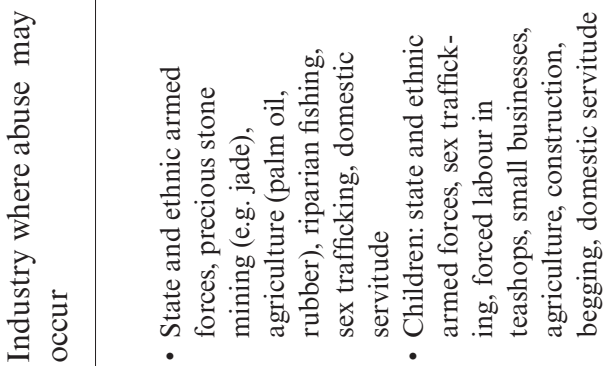

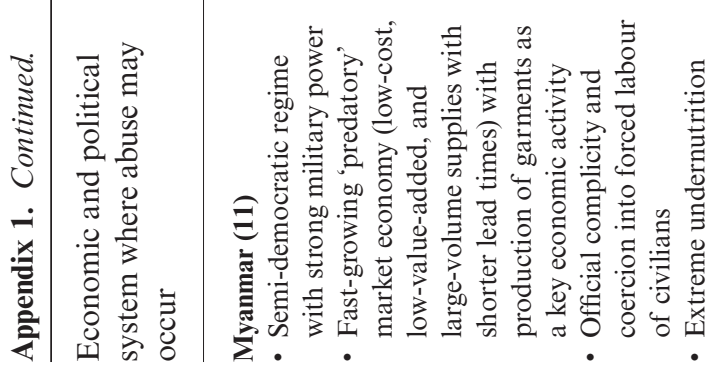




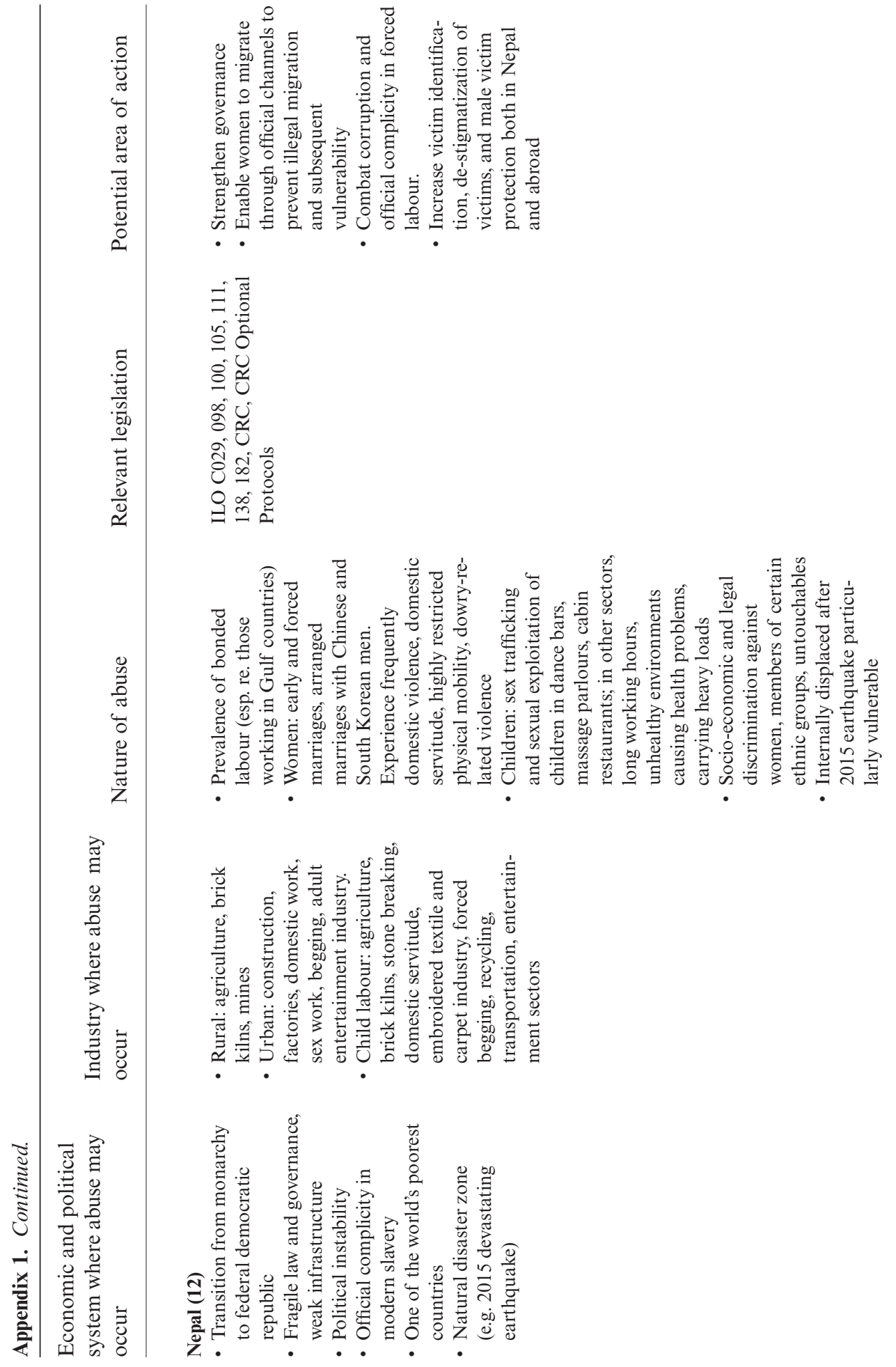




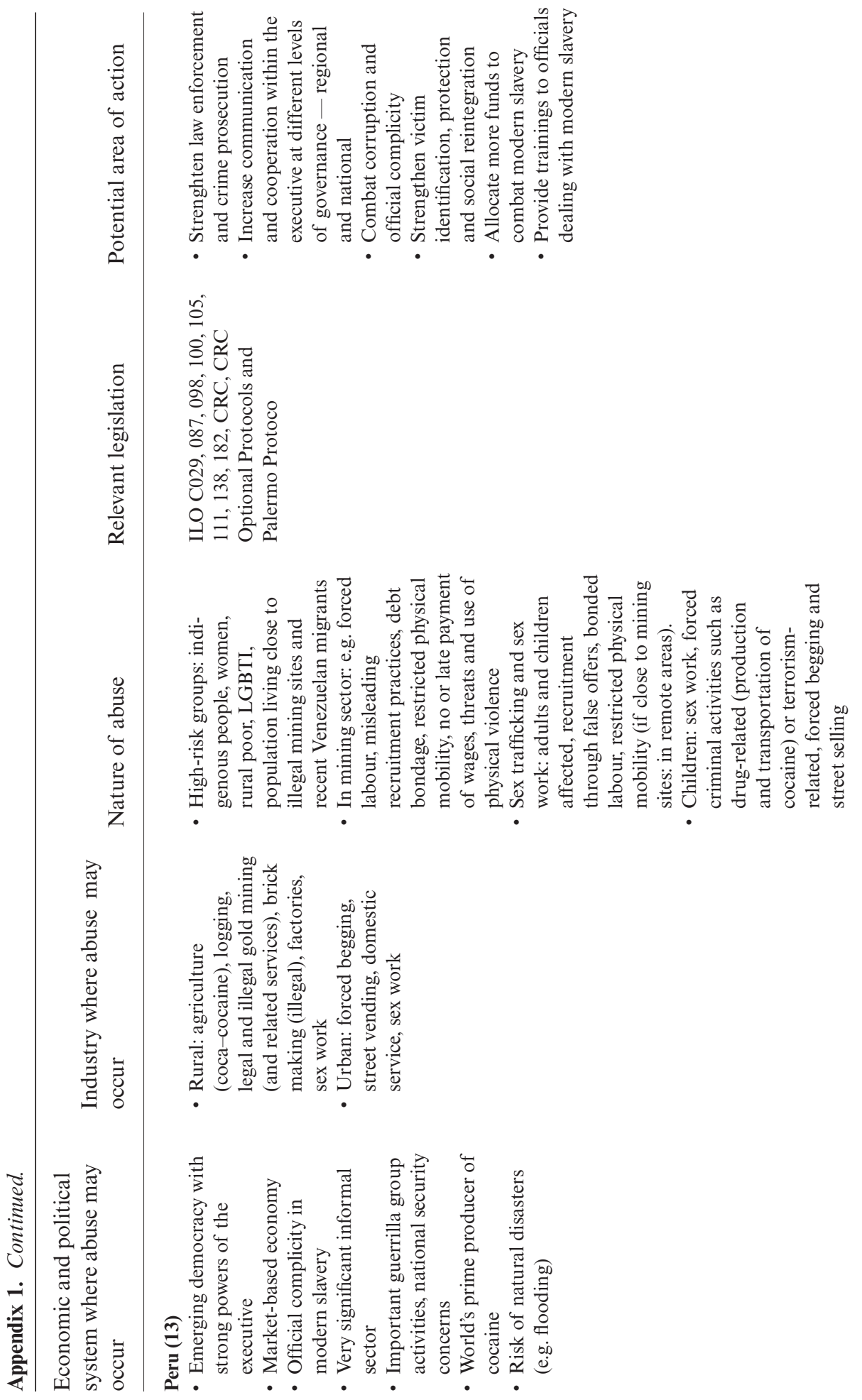




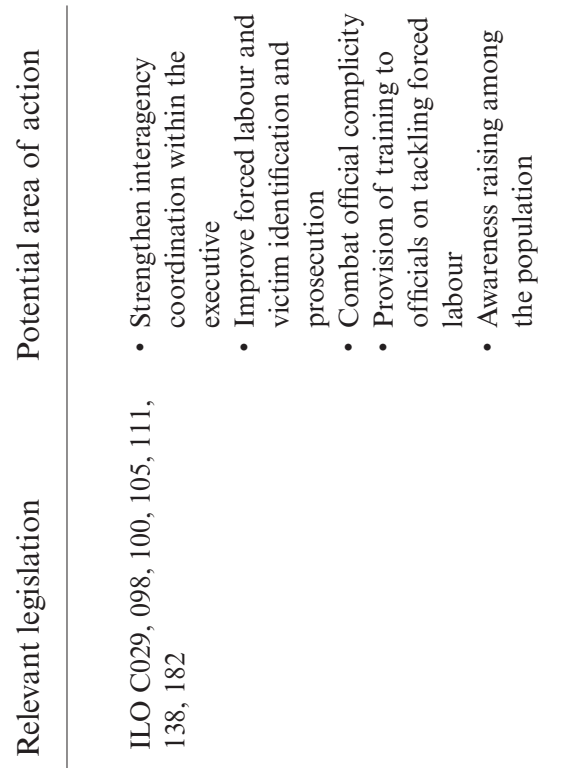

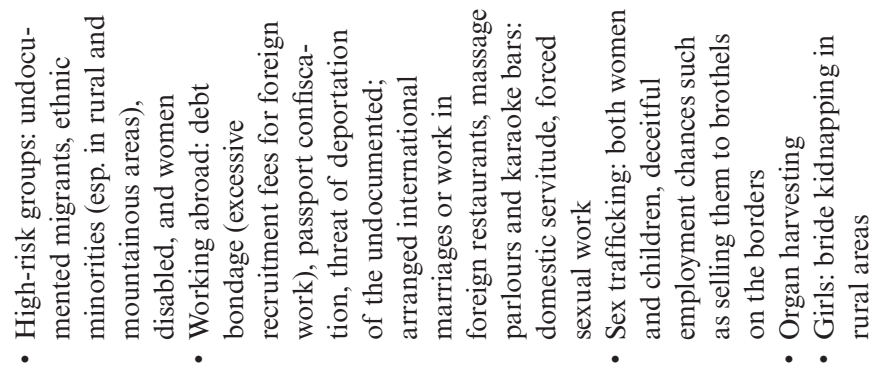

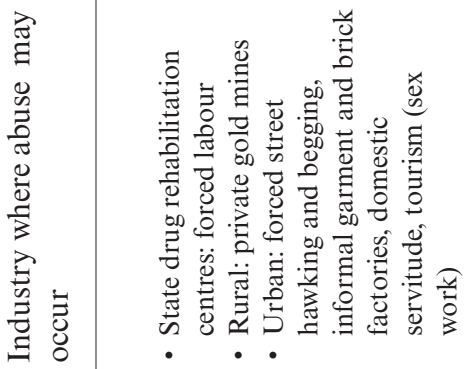

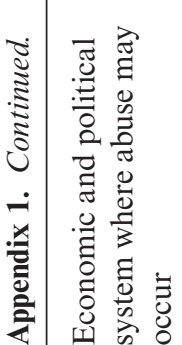

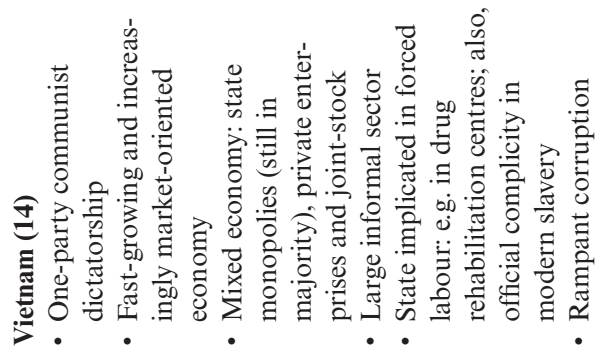




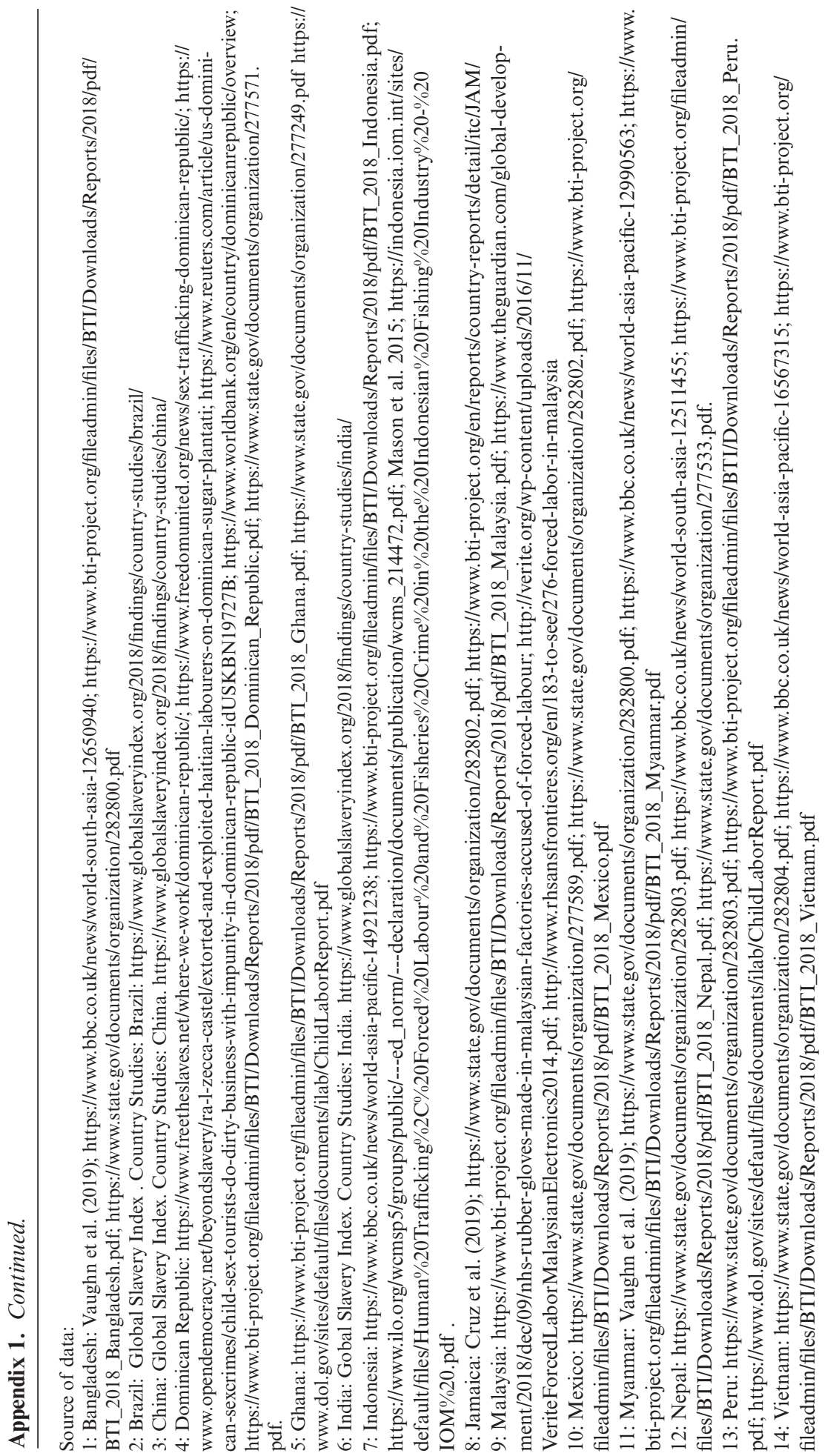

